UNITED STATISS

DEPPARTMENTT OF THE INTERRIOR

Geological Survey

Washington

THE IFON KING INO. I COFPHR PFOSPECT, KASAAIN PENINSULA; PRINCE OF WATES ISEAND, SOUTHEASTHRN ALASKA
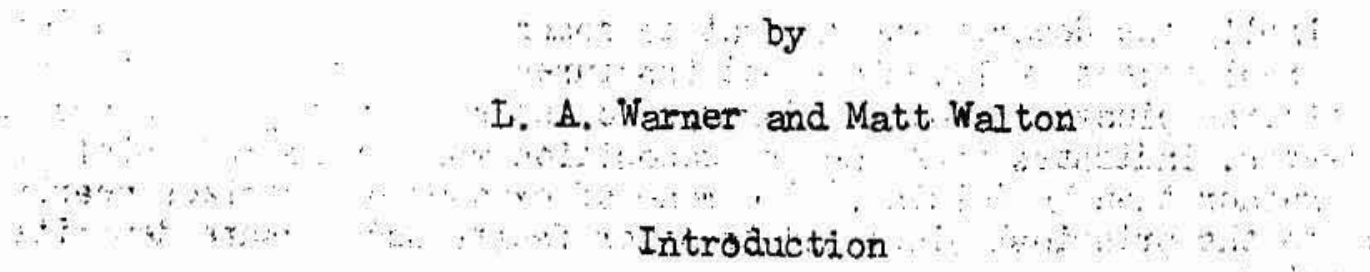

The copper prospect on the Iron King No. I claim (see fig. 1) is 0.9 mile N. $63^{\circ}$ W. of the village of Kasaan on Prince of Wale's Istand, southeastern Alaska. By Forest Service trail the distance from Kasan is 1.5 miles. The prospect is at al atitude of 50 feet and"is about 250 feet from the shore of Kastan Bay. The claim is owned by James Coleman; who also owns the eliaim covering the nearby Poor Man iron deposit. Development at the copper prospect consists of a group of small pits, trenches, and stripped areas within an erea 200 feet by 100 feet. The vicinity is almost completely covered by glacial deposits, alluvium and tegetation.

In September 1942 the Geological Survey made geologic, topographic, and magnetic surveys of the deposit and the adjacent.countiry If . The Bureau of Mines trenched and sampled the deposit in OCtober 1942 and drilled it in February and March 1943, at which time the drill cores, pits, and trenches were examined by the Geological Survey: This report summarizes the results of the earlier Geological Survey examination and presents the geologic results of the exploration by the Bureau of Mines:

\title{
Geology
}

The principal country rock at the prospect is the Kasaan greenstone, which, as el sewhere on the Kasaan Peninsula, has been folded and metamorphosed $2 \%$. Northeast- and north-trending dikes (bostonite and lamprophyre) cut the greenstone. Ninor faulting has taken place along northeast and northwest. fractures. The rocks are shattered and break readily into small pieces. Close to the deposit both the greenstone and the dikes are epidoti zed.

If Walton, Matt, The Iron King No. I copper prospect, Kasaan Peninsula, Prince of Wales Island, southeastern Alaska, U: S. Ceol. Survey report to war agencies, Dec. 1942.

2/ Wright, G. W., Geology and ore deposits of Copper Mountain and Kasaan Peninsula, Alaska: U. S. Geol. Survey Prof. Paper 87, p. 68, 1915. 


\section{Ore deposit}

Exposures of ore are largely confined to a zone approximately 150 feet $10 \mathrm{ng}$ and averafing between 10 and 15 feet wide (see fig. 2). The boundaries of this zone are irregular and poorly exposed. It trends about N. $15^{\circ} \mathrm{E}$., but its dip is not definitely known. Trench no. 1 (see fig. 2) exposes a well-defined contact bötween magnetite and sulfide ore wich strikes about $\mathrm{N}$. $15^{\circ} \mathrm{N}$. and dips $65^{\circ} \mathrm{NW}$. This contact seems to indicate the approximate attitude of the deposit.

Originally the deposit was thought to comprise two small ore bodies formed by replacement of limestone and fractured greenstone along the axis of an anticline plunging about 40 degrees to the southwest $3 /$. Subsequent work, however, indicates that the ore deposition was controlled mainly by faulting rather than by folding. The mo of exposed ore strikes nearly parallel to the principal dikes and to other faults and fissure deposits in the region.

A dip-needle survey of the covered area-surrounding the deposit demonstrated that the magnetic attraction of the ore body diminishes rapidly away from its outcrop. Old prospect trenches around the present exposures have largely slumped in, but no ore was observed in the material thrown out. Thus it is inferred that the deposit on the surface does not extend much beyond the area of outcrop.

The principal ore minerals are magnetite, prrife; and chalcopyrite. Of these magnetite is the earliest minergi and seems to here replaced the greenstone;' whereas the sulfide minerals fill fractures which eut the : : greenstone and the magnetate'. Magnetite is most abondent at the nor thern end of : the body where some ore contains as much as 50 percent of iron. The magnetite content decreases to the south and the southern part of , the body consists mo stly of mineralized greenstone in which pyrite and chal copyrite occur in a network of veinlets. Here magnetite is found locally as disseminated grains. Judging from the samples taken by the Bureau of:Mines at intervals along the bady, chalcopgrite, though not: eveniy distributedis is about as abundaut in the northern as in the southern part: of the deposit.

The trenches and drill holes: of the:Bureau of Mines are: shown on the accompanying map and sections (sée figs: 2 and 3 ). Trench! no: 1 exposes a band of magnetite ore about 3 feet wide: Bast of the magnetite for 8 feet is minerali zed greenstone containing pyrite and chalcopyrite. Although this material appears to be very low grade, the analyses indicate that it contains more than 1.5 per cent of copper. West of the magnetite is about 8 feet of sulfide ore. In trench no. 2 magnetite and sulfide ore are rather intimately assoei ated and the ore extends farther east than in trench no. 1. About 5 feet of minerali-ed greenstones rexposed at the 
east end of trench no. 4. The western part of trench no. 3 is now covered but mineralized greenstone was encountered here at the time the trench was excavated. Analyses of five-foot channel samples taken from trenches nos. 3 and 4 show that the material contains about 2 percent of copper.

Drill holes were inclined southeasterly from two places on the west side of the deposit. Two holes, nos. 17 and $17 \mathrm{~A}$, were put down from the southern location and one, no. 15, from the northern. A fourth hole, no. 18, was inclined northwesterly from a point on the east side of the ore body. None of the cores contain any ore minerals other than occasional grains of pyrite and chalcopyrite. Holes nos. 15, 17, and 17A encountered a dike at the previously inferred position of the ore body. Hole no. 18, if it had been continued about 20 feet farther, would probably have entered the dike below the footwall boundary of the deposit (see fig. 3). The dike is exposed only near the west end of trench no. 4. From the drillhole data it appears to be about 20 feet thick, to strike approximately $\mathbb{N}$. $15^{\circ} \mathrm{E}$. , and to dip about $650 \mathrm{SE}$. Whether or not the deposit extends to or beneath the dike has not been shown by the drilling.

\section{Reserves}

Twenty-nine channel samples were cut by the Bureau of Mines from the trenches and outcrops. The analytical data from these sarmples were made available by the Burean of Mines and indicate that the deposit contains an average of about 2 percent of copper and minor amounts of gold and silver. On the basis of the surface outcrops the body appears to be about 150 feet long and to average between 10 and 15 feet wide. No data are available on the depth to which the deposit extends. Assuming that the deposit extends, without change in length or width, to the large dike at an average depth of 30 feet, it contains about 5,500 tons of ore.

February, 1944 





United States Department of the Interior Geological Survey

FIGURE 2

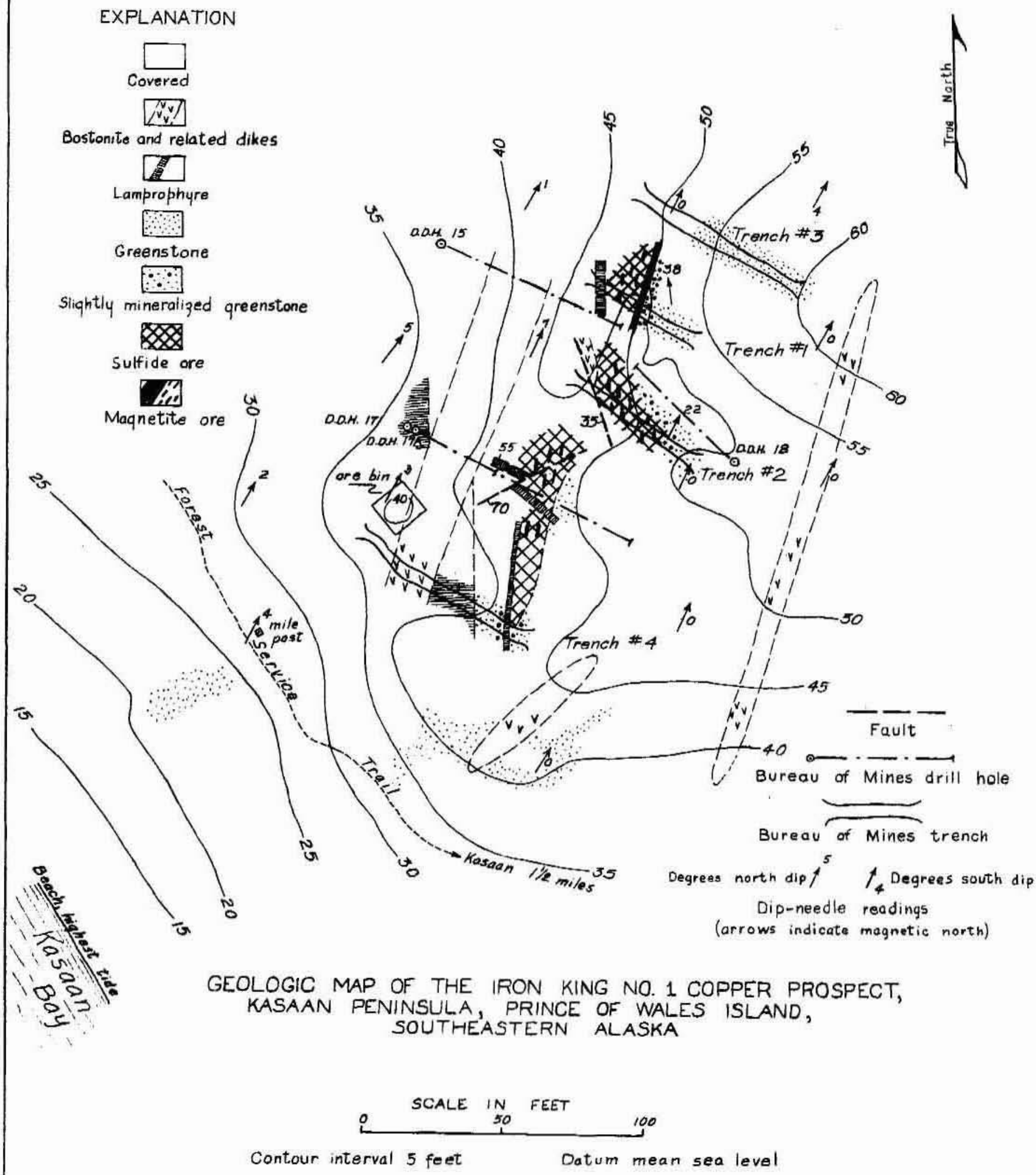

L.A. Warner, 1943 


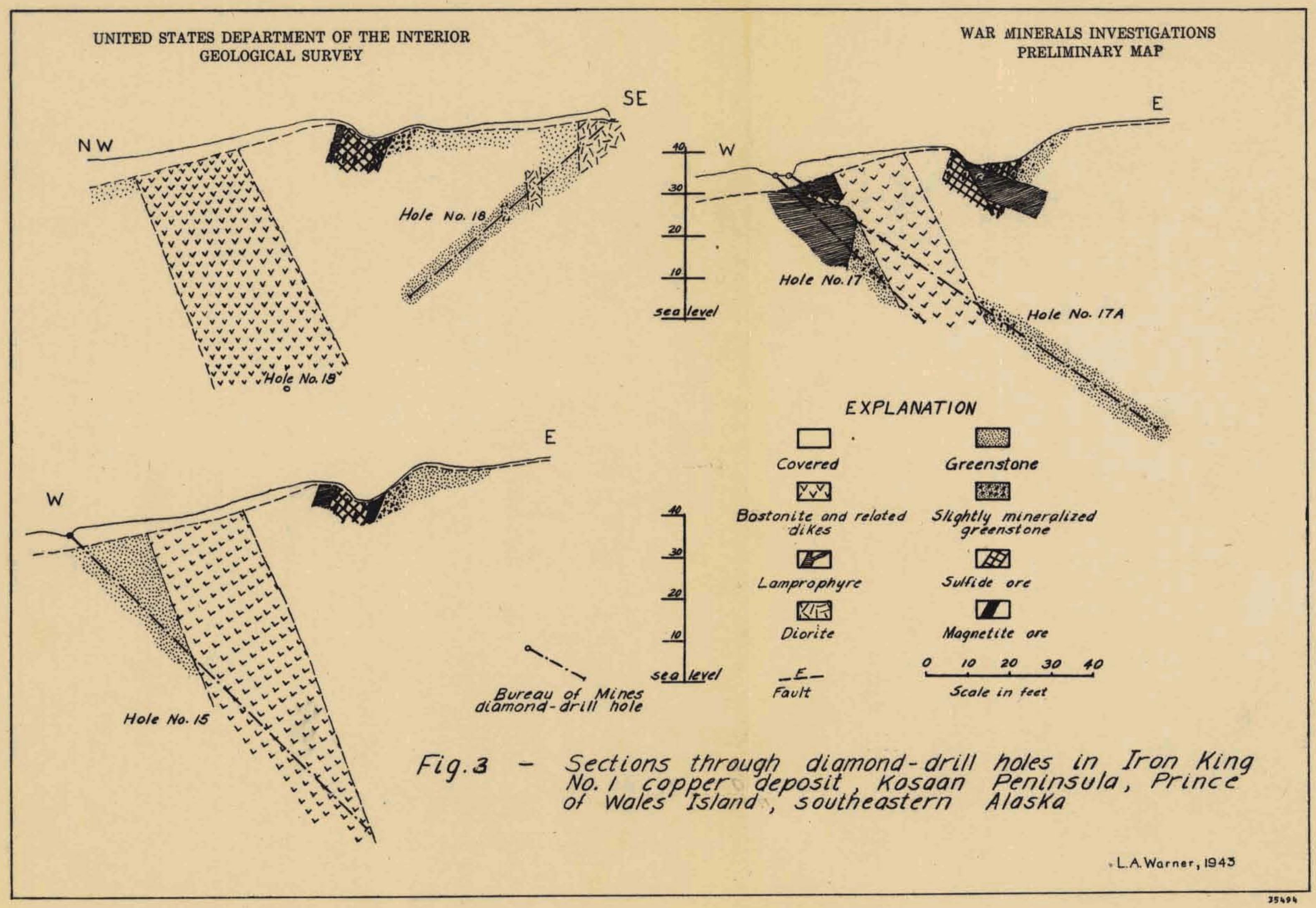

